\title{
Coastal groundwater systems: mapping chloride distribution from borehole and geophysical data
}

\author{
Mohammad Azizur Rahman' • Qian Zhao ${ }^{2} \cdot$ Helga Wiederhold ${ }^{3}$ (D) $\cdot$ Nico Skibbe $^{3}$ - Eva González ${ }^{4}$ Nico Deus $^{4}$. \\ Bernhard Siemon ${ }^{5} \cdot$ Reinhard Kirsch ${ }^{6} \cdot$ Jörg Elbracht ${ }^{4}$
}

Received: 14 May 2020 / Revised: 4 September 2020 / Accepted: 7 January 2021 / Published online: 21 January 2021

(c) The Author(s) 2021

\begin{abstract}
Information on chloride $(\mathrm{Cl})$ distribution in aquifers is essential for planning and management of coastal zone groundwater resources as well as for simulation and validation of density-driven groundwater models. We developed a method to derive chloride concentrations from borehole information and helicopter-borne electromagnetic (HEM) data for the coastal aquifer in the Elbe-Weser region where observed chloride and electrical conductivity data reveal that the horizontal distribution of salinity is not uniform and does not correlate with the coastline. The integrated approach uses HEM resistivity data, borehole petrography information, grain size analysis of borehole samples as well as observed chloride and electrical conductivity to estimate $\mathrm{Cl}$ distribution. The approch is not straightforward due to the complex nature of the geology where clay and silt are present. Possible errors and uncertainties involved at different steps of the method are discussed.
\end{abstract}

Keywords Helicopter-borne electromagnetics · Coastal aquifer - Chloride distribution · Groundwater electrical conductivity $\cdot$ Formation factor

Mohammad Azizur Rahman

azizur1978@yahoo.com

Qian Zhao

zhqian1992@hotmail.com

$\triangle$ Helga Wiederhold

helga.wiederhold@leibniz-liag.de

Nico Skibbe

nico.skibbe@leibniz-liag.de

Eva González

eva.gonzalez@lbeg.niedersachsen.de

Nico Deus

nico.deus@lbeg.niedersachsen.de

Bernhard Siemon

bernhard.siemon@bgr.de
Reinhard Kirsch geo-i@mytng.de

Jörg Elbracht

joerg.elbracht@lbeg.niedersachsen.de

148 Pepperhill Road, M167PE Manchester, UK

2 Cai Hong Gong Yu 524, 26 Makan Road, Xili street, Nanshan District, Shenzhen, Guangdong, China

3 Leibniz Institute for Applied Geophysics, Stilleweg 2, 30655 Hannover, Germany

4 Geological Survey of Lower Saxony (LBEG), Stilleweg 2, 30655 Hannover, Germany

5 Federal Institute for Geosciences and Natural Resources (BGR), Stilleweg 2, 30655 Hannover, Germany

6 GeoImpulse, Graf-Spee-Str. 4-6, 24105 Kiel, Germany 


\section{Küstennahe Grundwassersysteme: Kartierung der Chloridverteilung aus Bohrdaten und Geophysik}

\section{Zusammenfassung}

Informationen zur Chloridverteilung im Grundwasserleiter sind für Planung und Management von Grundwasserressourcen in Küstengebieten sowie für die Simulation und Validierung von dichtegesteuerten Grundwassermodellen von wesentlicher Bedeutung. Es wurde eine Methode zur Ableitung der Chloridkonzentration aus Bohrungen und hubschrauber-elektromagnetischen Daten (HEM) entwickelt und für den Küstengrundwasserleiter des Elbe-Weser-Dreiecks eingesetzt. Die dort beobachteten Chloriddaten und elektrischen Leitfähigkeitsdaten zeigen eine ungleichmäßige horizontale Verteilung des Salzgehalts, die nicht mit der Küstenlinie korreliert. Der integrierte Ansatz verwendet HEM-Daten des spezifischen elektrischen Widerstands, Bohrloch-Petrographie-Informationen, Korngrößenanalysen von Bohrlochproben sowie beobachtete Chlorid- und elektrische Leitfähigkeitswerte, um die Chlorid-Verteilung abzuschätzen. Mögliche Fehler und Unsicherheiten bei den verschiedenen Schritten des Verfahrens werden diskutiert.

Schlüsselwörter Hubschrauber-Elektromagnetik · Küstenaquifer · Chloridverteilung · Elektrische Leitfähigkeit des Grundwassers · Formationsfaktor

\section{Introduction}

Worldwide coastal aquifers are increasingly endangered by saline water intrusion from oceans and rivers (van Weert et al. 2009). Saline water intrusion is triggered by several driving forces, natural and anthropogenic, that act on different spatial and temporal scales. Changes in rainfall patterns and sea level rise driven by climate change interact with increased groundwater exploitation, land drainage, and urbanization (White and Kaplan 2017). The effects of these driving forces make sustainable coastal zone groundwater management very complicated. Accurate groundwater resource assessment and information on the spatial distribution of salinity is required (Barlow and Reichard 2010). Groundwater resource assessment allows the planning of drinking water supplies which involves considering present and future water demand (Cosgrove and Loucks 2015). Understanding the three-dimensional distribution of chloride supports the siting of groundwater extraction wells and the definition of the proper filter depth. Groundwater models can support this planning action (Dogrul et al. 2016) but for density-dependent groundwater modelling, information on existing freshwater head and chloride distribution is required at sufficient resolution.

Direct and indirect methods are available to estimate chloride (Cl) content in the groundwater (Goes et al. 2009). Direct methods involve groundwater sampling and measurement of $\mathrm{Cl}$ concentration in the laboratory. This analysis is more expensive than the indirect measurement of groundwater electrical conductivity $\left(\mathrm{EC}_{\mathrm{w}}\right)$ that can be measured in the field by a conductivity meter (Peinado-Guevara et al. 2012). It is common practice to install monitoring stations for groundwater levels and salinity measurements, and in some cases, data availability is adequate and fulfils the requirement for groundwater modelling. However, as the chloride concentration varies with depth, multilevel moni- toring stations would be necessary (Margane 2004), but are not often realized due to cost issues.

Some indirect survey techniques can support the required data density for mapping the chloride concentration in a coastal aquifer (Table 1). These indirect techniques are mostly based on $\mathrm{EC}_{\mathrm{w}}$ or the bulk electrical resistivity $\left(\mathrm{R}_{\mathrm{b}}\right)$. Both can be translated into chloride concentration by empirical equations that require aquifer and water properties, such as the formation factor or porosity.

A number of studies apply geophysical surveys for salinity estimation or fresh-saline groundwater interface delineation. In particular, airborne electromagnetic (AEM) methods enable spatial mapping of $\mathrm{R}_{\mathrm{b}}$ with high resolution (in the order of tens of meters to hundreds of meters) along the line and acceptable resolution (hundreds of meters) across the lines (Siemon et al. 2009). Vertical resolution decreases with depth (from meters to tens of meters) and depends on system parameters and the subsurface conductivity distribution, which limits the depth of investigation (Christiansen and Auken 2012). Large-scale groundwater surveys increasingly apply AEM methods to investigate large areas in reasonable time and at relatively low costs (Paine and Minty 2005; Siemon et al. 2009). AEM results have been used not only for mapping purposes, but also as base-line data estimation for geological and groundwater modelling (e.g. De Louw et al. 2011; Gunnink et al. 2012; Sulzbacher et al. 2012).

Several large-scale AEM studies for fresh-saline groundwater mapping have used fixed $R_{b}$ thresholds or gradients to distinguish between fresh and saline water (e.g. Siemon et al. 2009 (island of Borkum), Viezzoli et al. 2010 (Venice lagoon), Kirkegaard et al. 2011 (Hvide Sande, Denmark), Pedersen et al. 2017 (Zeeland, the Netherlands)). Further AEM studies were supported by additional information including Electric Cone Penetration Tests (ECPT; De Louw et al. 2011; Siemon et al. 2019 (both in the Nether- 
Table 1 Overview of methods that can be used for $\mathrm{R}_{\mathrm{b}}, \mathrm{EC}_{\mathrm{w}}$, porosity, and chloride estimation

Tab. 1 Überblick über Verfahren zur Bestimmung von $\mathrm{R}_{\mathrm{b}}, \mathrm{EC}_{\mathrm{w}}$, Porosität und Chloridverteilung

\begin{tabular}{|c|c|c|c|}
\hline Method Type & $\begin{array}{l}\text { Information availability } \\
\text { (D: dimension) }\end{array}$ & Parameter & Characteristics \\
\hline $\begin{array}{l}\text { Electrical borehole } \\
\log s^{\mathrm{a}}\end{array}$ & $1 \mathrm{D}$ & $\mathrm{R}_{\mathrm{b}}$, lithology & Indirect method (in-situ) \\
\hline $\begin{array}{l}\text { Electrical cone penetra- } \\
\text { tion test (ECPT) }\end{array}$ & $1 \mathrm{D}$ & $\mathrm{EC}_{\mathrm{w}}$, lithology & Indirect method (in-situ) \\
\hline Direct push ${ }^{\mathrm{a}}$ & $1 \mathrm{D}$ & $\mathrm{EC}_{\mathrm{w}}, \mathrm{R}_{\mathrm{b}}, \mathrm{Cl}$ & $\begin{array}{l}\text { Direct and indirect value of chloride; costly and might not be pos- } \\
\text { sible to perform in a regional scale with high resolution (in-situ) }\end{array}$ \\
\hline $\begin{array}{l}\text { Vertical electrical } \\
\text { sounding (VES) }\end{array}$ & $1 \mathrm{D}$ & $\mathrm{R}_{\mathrm{b}}$ & $\begin{array}{l}\text { Indirect method, problem due to equivalent inversion results (sur- } \\
\text { face method) }\end{array}$ \\
\hline $\begin{array}{l}\text { Electrical resistivity } \\
\text { tomography (ERT) }\end{array}$ & $2 \mathrm{D}, 3 \mathrm{D}$ & $\mathrm{R}_{\mathrm{b}}$ & Indirect method (surface method) \\
\hline $\begin{array}{l}\text { Electromagnetic }(\mathrm{EM}) \\
\text { method }\end{array}$ & $1 \mathrm{D}, 2 \mathrm{D}$ & $\mathrm{R}_{\mathrm{b}}$ & Indirect method (surface method) \\
\hline $\begin{array}{l}\text { Helicopter-borne EM } \\
\text { (HEM) }\end{array}$ & $3 \mathrm{D}$ & $\mathrm{R}_{\mathrm{b}}$ & 3D high-resolution data; indirect method (airborne method) \\
\hline $\begin{array}{l}\text { Nuclear magnetic reso- } \\
\text { nance (NMR) }\end{array}$ & $1 \mathrm{D}$ & $\begin{array}{l}\Phi \text {, hydraulic } \\
\text { conductivity }\end{array}$ & $\begin{array}{l}\text { Indirect method; used in the estimation of water content and as- } \\
\text { sessment of hydraulic conductivities (surface method) }\end{array}$ \\
\hline $\begin{array}{l}\text { Spectral induced polar- } \\
\text { ization (SIP) }\end{array}$ & $1 \mathrm{D}, 2 \mathrm{D}$ & $\mathrm{R}_{\mathrm{b}}$ & Indirect method (surface method) \\
\hline Grainsize Analysis ${ }^{\mathrm{a}}$ & $0 \mathrm{D}$ & $\Phi$ & Used in the empirical formula to estimate FF (laboratory) \\
\hline $\begin{array}{l}\text { Ground penetrating } \\
\text { radar }\end{array}$ & $1 \mathrm{D}, 2 \mathrm{D}$ & Water content & $\begin{array}{l}\text { Used in the empirical formula to estimate water content and poros- } \\
\text { ity and afterwards FF (surface method) }\end{array}$ \\
\hline Monitoring wells ${ }^{\mathrm{a}}$ & 0D, time series & $\mathrm{Cl}$ & $\begin{array}{l}\text { Direct method; it involved extensive cost to get high resolution } \\
\text { horizontal and vertical chloride information (in-situ) }\end{array}$ \\
\hline Monitoring wells ${ }^{\mathrm{a}}$ & $0 \mathrm{D}$, time series & $\mathrm{EC}_{\mathrm{w}}$ & Indirect method (in-situ) \\
\hline
\end{tabular}

${ }^{\text {a }}$ Data type that were used in this study

lands)), ground based $\mathrm{EM}, \mathrm{EC}_{\mathrm{w}}$ and petrography information (Chongo et al. 2015 (Zambia)), or borehole results (Pedersen et al. 2017).

Ground-based resistivity methods like Vertical Electric Sounding (VES) for fresh-saline water interface mapping were used by Kumar et al. (2015 (India)), supported by water quality parameter estimation, and Goes et al. (2009 (the Netherlands)), supported by ECPT, borehole logs, $\mathrm{EC}_{\mathrm{w}}$ and chloride measurements. Paine (2003 (Texas, USA)) used AEM and borehole induction logs to map the resistivity distribution in the groundwater.

The spatial distribution of chloride in groundwater was mapped by Delsman et al. (2018 (Zeeland, the Netherlands)) using frequency-domain helicopter-borne electromagnetic (HEM) and Peinado-Guevara et al. (2012 (Mexico)) using VES; both studies were supported by chloride measurements.

In this paper an integrated approach is presented to estimate the formation factor distribution from HEM resistivity data, borehole petrography information, and grain size analysis of borehole samples. $\mathrm{Cl}$ concentrations are then calculated from observed chloride and electrical conductivity (EC) values. A final map is produced showing the $\mathrm{Cl}$ distribution in the aquifer at several depth intervals. The method is applied to a coastal area of Lower Saxony (Ger- many) between the Weser and Elbe rivers. The obtained $\mathrm{Cl}$ distribution is used to model its future development under climate change conditions (González et al. 2020). The method is general and applicable to other regions with comparable geological conditions. We critically discuss possible errors and uncertainties involved at different steps of the method.

\section{Study area}

The study area is situated in the coastal area of Lower Saxony, Germany, between the Elbe and Weser rivers (Fig. 1). This study is performed as part of the project TOPSOIL in the framework of the EU INTERREG VB North Sea Region Programme. The analysis covers an area of about $1700 \mathrm{~km}^{2}$, and the depth range covered by the HEM survey is between the surface and $30-160 \mathrm{~m}$ depending on the bulk electrical conductivity distribution in the subsurface. The study area is bounded by the North Sea in the west (ca. $37 \mathrm{~km}$ coastline) and the Elbe River in the north and east $(80 \mathrm{~km}$ long reach). Another major river within the area is the Oste (reach ca. $50 \mathrm{~km}$ ). The topography of the area is relatively flat (marshlands) with some highlands (Geest) 


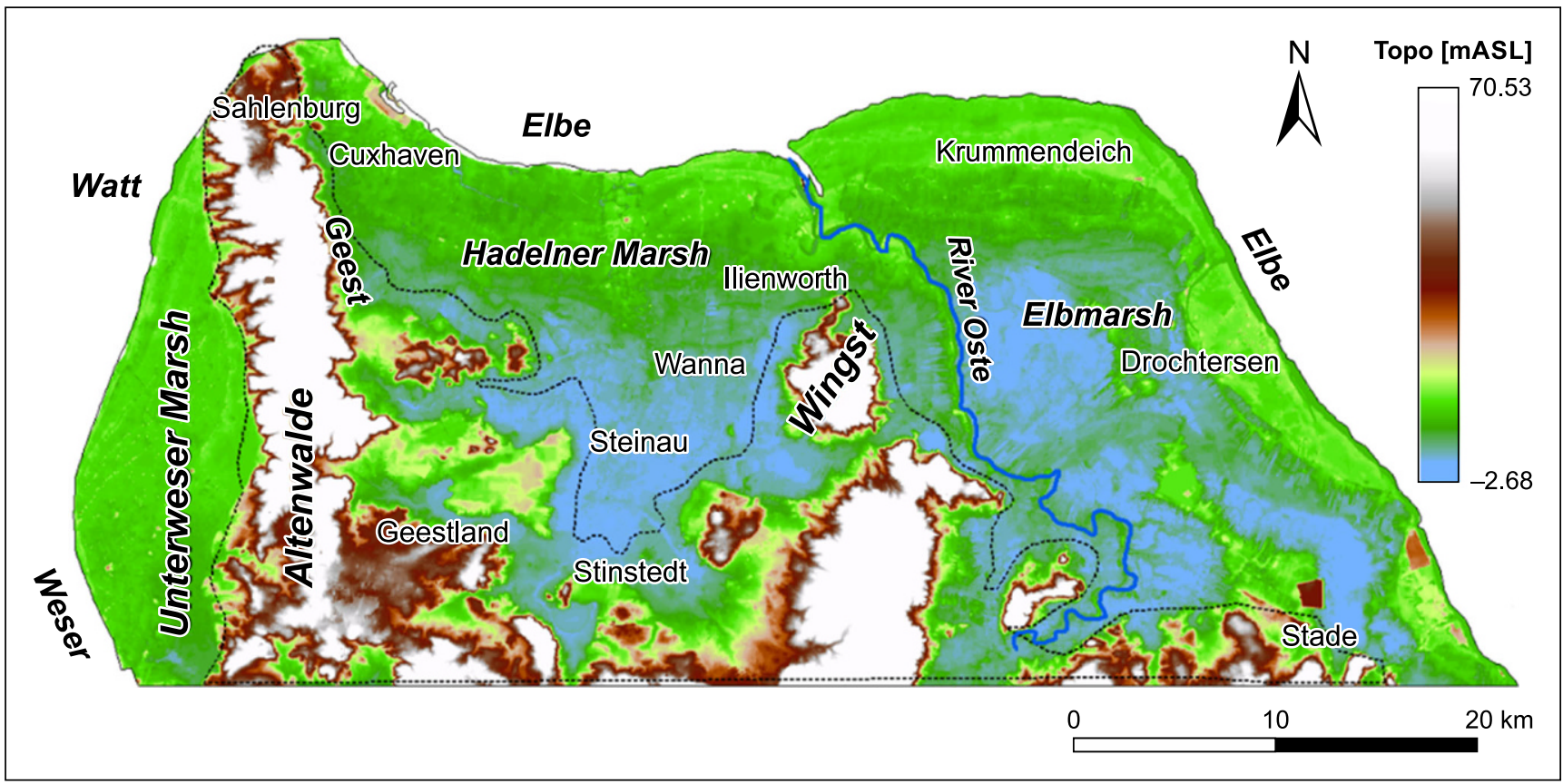

Fig. 1 Study area showing the topography. The black dotted line is the separation between marshlands and highland (Geest)

Abb. 1 Untersuchungsgebiet mit Topographie. Die schwarz gepunktete Linie trennt Marsch und Geest

in the west and in the south. Terrain elevations are in the range between $-2 \mathrm{~m}$ to $71 \mathrm{~m}$ above sea level (ASL).

\section{Geology and hydrogeology of the area}

The geology of Elbe-Weser region is relatively complex and characterized by sedimentation in Quaternary glacial and interglacial periods as well as by the Holocene sea level rise. During the Elsterian and the Saalian glaciations, the glacial maximum reached the Central German Basin; thus the Elbe-Weser region was covered entirely by ice several times (Ehlers 2011). During this period, massive glaciofluvial sediment bodies were deposited, mainly consisting of sand and gravel with an average thickness of $20 \mathrm{~m}$. In addition, during the Elsterian glaciation, tunnel valleys up to $500 \mathrm{~m}$ deep were formed by subglacial erosion and filled predominantly by glaciofluvial sand. The valleys are covered by so called 'Lauenburger Clay' (Kuster and Meyer 1979). Due to sea level rise in the following Eem interglacial, the sea extended into the region bounded by the moraine ridges of Land Hadeln (Höfle et al. 1985). The maximum of the Weichselian glaciation did not reach the Elbe-Weser region (Streif and Köster 1978) so that the area has only been influenced by proglacial processes. Brackishmarine sediments of the marshlands were deposited in the Holocene (Streif and Köster 1978).

Pleistocene and partly Pliocene sands, and the occasional presence of gravel, form the upper aquifer of the Elbe-Weser region with local variations. The uppermost groundwater storage in the Elbmarsch consists of Weichselian fluvial sand and glaciofluvial sand of the Drenthe glacial (Saalian). In the Unterweser Marsch and the Geest area, Pleistocene sand forms the upper aquifer. The tunnel valley aquifer consists of Elsterian glaciofluvial sediments. The hydraulic contact between the tunnel valley aquifer and the surrounding Pliocene sand is discontinuous. The Lauenburger Clay in the region is the most important dividing layer between the different aquifers (Elbracht et al. 2016). Hydraulic conductivity values of the Saalian aquifer at the region range between $10^{-4}$ and $10^{-3} \mathrm{~m} / \mathrm{s}$ (Reutter 2011). Clayey Holocene sediments in the marshlands work as a protective layer for the groundwater, whereas the protection potential of groundwater in the moraine ridges is very low. Groundwater in the marshlands has a high salinity in contrast to the moraine ridges, where groundwater is fresh (Elbracht et al. 2016).

The study area lies between the moraine ridges of $\mathrm{Al}-$ tenwalde in the west and the Elbe River in the east, including the Hadelner Marsch. The area is characterized by low groundwater recharge (between $51 \mathrm{~mm} /$ year and $150 \mathrm{~mm} /$ year) in the marshlands and high groundwater recharge (between $101 \mathrm{~mm} /$ year and $400 \mathrm{~mm} /$ year) with a relatively high groundwater level (>10 m ASL) (NIBIS $^{\circledR}$ Kartenserver 2018 ) in the moraine ridges. The groundwater level in the study area follows the topography. In general, the groundwater level varies between $-4 \mathrm{~m}$ and $28 \mathrm{~m}$ ASL. 


\section{Source of salinity in the aquifer}

The primary source of salinity in the aquifer is saline water intrusion from the North Sea (average $\mathrm{Cl}$ concentration of North Sea water close to the coast is about $16,000 \mathrm{mg} / \mathrm{l}$ ) and from the Elbe River (average $\mathrm{Cl}$ concentration between $9000 \mathrm{mg} / \mathrm{l}$ and $40 \mathrm{mg} / \mathrm{l}$ (WSV 2019)). The chloride concentration of the Elbe River decreases upstream. Salt also accumulated in the shallow aquifer below Unterweser Marsch, Hadelner Marsch, and Elbmarsch due to Holocene transgressions (leading to saline water infiltrating vertically from the flooded area before the dykes were built). At Stade, a salt structure exists that contains a different geochemical signature than the saline water originating from the sea (Rahman et al. 2018). The contribution of this salt structure to the groundwater salinity at Stade is yet to be quantified.

\section{Methodology}

The following steps were performed to estimate the $\mathrm{Cl}$ distribution from HEM data: (1) analysis of borehole information, (2) formation factor estimation, (3) assigning petrography classes to HEM resistivity at different depths, (4) estimation of groundwater electrical conductivity $\left(\mathrm{EC}_{\mathrm{w}}\right)$, (5) establishment of a relation between $\mathrm{EC}_{\mathrm{w}}$ and $\mathrm{Cl}$, (6) 2-D

Table 2 Main data type used and number of samples obtained from different institutions

Tab. 2 Liste der verwendeten Datentypen und Anzahl der Proben, die von verschiedenen Institutionen zur Verfügung gestellt wurden

\begin{tabular}{lll}
\hline Data & Volume & Sources \\
\hline $\begin{array}{l}\text { Petrographic infor- } \\
\text { mation }\end{array}$ & $\begin{array}{l}\text { 8622 Boreholes } \\
\text { 94,237 Samples } \\
\text { 8rain size Analysis }\end{array}$ & $\begin{array}{l}\text { 23BEG } \\
\text { 641 Samples }\end{array}$ \\
& $\begin{array}{l}\text { Geozentrum } \\
\text { Hannover } \\
\left(\mathrm{BGR}^{\mathrm{b}}, \mathrm{LBEG}\right. \\
\text { and LIAG })\end{array}$ \\
$\begin{array}{l}\text { Electrical Logs } \\
\text { 136 Boreholes }\end{array}$ & $\begin{array}{l}\text { LBEG } \\
\text { 5406 Samples } \\
\text { Cuxhaven, Hadeln, Bre- } \\
\text { merhaven, Glückstadt: } \\
\text { ca. 3.3 Mio resistivity } \\
\text { models }\end{array}$ & BGR \\
1936 Samples & \\
$\begin{array}{l}\text { Observed EC } \\
\text { and chloride from } \\
\text { groundwater quality } \\
\text { monitoring }\end{array}$ & & NLWKN \\
$\begin{array}{l}\text { Observed EC } \\
\text { chloride from direct } \\
\text { push test }\end{array}$ & 350 Samples & \\
\hline
\end{tabular}

${ }^{\mathrm{a}}$ Geological Survey of Lower Saxony

${ }^{b}$ Federal Institute for Geosciences and Natural Resources

${ }^{\mathrm{c}}$ Leibniz Institute for Applied Geophysics

${ }^{\mathrm{d}}$ The Lower Saxony Water Management, Coastal Protection and Nature Conservation Agency interpolation of $\mathrm{Cl}$ data, and (7) manual inspection, validation and adjustment of $\mathrm{Cl}$ distribution.

All data were obtained from several secondary sources (Table 2). The data were checked for possible errors, consistency, then were processed after corrections. Python codes were written for step 1 to step 7 (except step 6) to perform the tasks quickly and efficiently. The codes are general and, therefore, applicable to any other comparable HEM survey area (unconsolidated sedimentary rocks) after minor modification. Golden Software Surfer 8 was used for 2D interpolation. A brief description of each step is given below.

\section{Analysis of borehole information}

Borehole description is considered as one of the primary sources of information to understand the horizontal and vertical distribution of the petrography at the study area. A total of 8622 boreholes with depths in the range of 1-2000 m were obtained from Geological Survey of Lower Saxony (LBEG) for the study area. Borehole ID, coordinates, depth, and corresponding petrographic symbols were extracted from the database. The petrographic symbols were converted to petrography descriptions using the geology key-symbol database of LBEG (LBEG 2018), e.g. T-U (clay to silt) was converted to 'silty clay'. Altogether, 13 petrography classes were defined this way and listed in Table 3, together with values for porosity and, if available, formation factor (FF). Afterwards, the petrography information was assigned to every meter depth of the borehole.

\section{Formation factor estimation}

The straightforward way to estimate the formation factor FF would result from its definition. $\mathrm{FF}$ is the ratio of $\mathrm{EC}_{\mathrm{w}}$ to the bulk conductivity of the fully saturated rock (Archie 1942) or, expressed in terms of resistivity, the quotient of the resistivity of the fully saturated rock $\left(\mathrm{R}_{\mathrm{b}}\right)$ and the resistivity of the pore water $\left(1 / \mathrm{EC}_{\mathrm{w}}\right)$. As information on $\mathrm{EC}_{\mathrm{w}}$ is not spatially available, we considered estimating FF from grain size data and porosity. FF was estimated using the following empirical equation (Taylor Smith 1971):

$\mathrm{FF}=\Phi^{-1.5}$

where $\Phi$ is the porosity of the sediment sample. This equation is for clay-free sediment, and is valid for $\Phi \leq 0.6$, which is within the limit for the porosities of our samples (except peat). Sediment porosity was estimated using the following equation (Vukovic and Soro 1992):

$\Phi=0.255\left(1+0.83^{\mathrm{U}}\right)$ 
Table 3 Formation factor and porosity of the 13 petrography classes, $\varepsilon$ is the standard deviation of corresponding parameter Tab. 3 Formationsfaktor und Porosität der 13 Petrographieklassen, $\varepsilon$ bezeichnet die Standardabweichung des jeweiligen Parameters

\begin{tabular}{lllllll}
\hline Petrography class & $\begin{array}{l}\text { Symbol after LBEG } \\
(2018)\end{array}$ & $\begin{array}{l}\text { Porosity } \\
(\Phi)\end{array}$ & $\varepsilon(\Phi)$ & $\begin{array}{l}\text { Average } \\
\text { FF }\end{array}$ & $\varepsilon$ FF) & $\begin{array}{l}\text { Sample numbers/reference (own analysis } \\
\text { if no reference) }\end{array}$ \\
\hline Clay & $\mathrm{T}$ & 0.42 & - & 2.50 & 0.60 & $\begin{array}{l}\text { 192/De Louw et al. (2011) } \\
\text { Silty Clay }\end{array}$ \\
Clayey Silt & $\mathrm{T}-\mathrm{U} / \mathrm{T}, \mathrm{U} / \mathrm{T}, \mathrm{S} 1$ & 0.41 & 0.01 & 2.50 & - & FF same as clay \\
Silt (clayey fine & $\mathrm{U}-\mathrm{T} / \mathrm{U}, \mathrm{T}$ & 0.46 & - & 3.20 & - & FF same as silt \\
sand) & & 0.46 & - & 3.20 & - & 299/De Louw et al. (2011) \\
Sandy Clay & $\mathrm{T}-\mathrm{S} / \mathrm{T}, \mathrm{S}$ & & & & \\
Sandy Silt & $\mathrm{U}-\mathrm{fS} / \mathrm{U}-\mathrm{ffS} / \mathrm{U}-\mathrm{S}$ & 0.42 & 0.00 & 4.41 & 0.19 & 4 \\
Clayey Sand & $\mathrm{S}, \mathrm{T} / \mathrm{fS}, \mathrm{T} / \mathrm{mS}, \mathrm{T}$ & 0.26 & - & 2.80 & 0.80 & $52 /$ De Louw et al. (2011) \\
Silty Sand & $\mathrm{fS}-\mathrm{U} / \mathrm{ffS}-\mathrm{U}$ & 0.40 & 0.05 & 3.95 & 0.68 & 481 \\
Fine Sand & $\mathrm{fS}$ & 0.39 & 0.02 & $4.33(3.2)^{\mathrm{a}}$ & 0.98 & 56 \\
Medium Sand & $\mathrm{mS}$ & 0.39 & 0.05 & $4.40(4.0)^{\mathrm{a}}$ & 0.77 & 106 \\
Coarse Sand & $\mathrm{gS}$ & 0.43 & - & 5.00 & - & Goes et al. (2009) \\
Gravel & $\mathrm{fG} / \mathrm{gG}$ & 0.31 & - & 7.00 & - & Goes et al. (2009) \\
Peat & $\mathrm{H}$ & - & - & 2.10 & 0.70 & 41/De Louw et al. (2011) \\
\hline
\end{tabular}

a The value in brackets is from de Louw et al. (2011)

where $\mathrm{U}$ is the coefficient of uniformity and defined as the ratio of $d_{60}$ to $d_{10}$ from grain size analysis. A total of 647 grain size analysis data at different depths from 83 boreholes were obtained from the LBEG, BGR, and LIAG databases.

The spatial distribution of grain size data is mainly limited to the Geest area in the western part of the study area, only a few samples are available in the marshlands. FF values of silt, clay, coarse sand, gravel and peat were obtained from the literature (e.g., De Louw et al. 2011; Goes et al. 2009). In addition, if petrography classes whose formation factor or porosity were not included in our database or the literature, we considered FF values from similar petrography classes (see details in Table 3).

\section{Assigning formation factor to HEM data at different depths}

BGR conducted airborne surveys covering the entire study area, simultaneously recording electromagnetic, magnetic, and radiometric data (Siemon et al. 2020). The electromagnetic data used here were acquired in 2000 for the Cuxhaven area (Siemon et al. 2013), in 2001 for the Bremerhaven area (Siemon et al. 2011), in 2004 for the Hadelner Marsch area (Siemon et al. 2017) and in 2008-2010 for the Glückstadt area (Steuer et al. 2013), all available at Produktcenter BGR (2017). After inversion of the frequency domain electromagnetic data by BGR using Levenberg-Marquardt inversion techniques (Sengpiel and Siemon 2000, Siemon et al. 2009), the layered vertical distribution of the bulk resistivity $R_{b}$ was obtained at sampling distances of $4 \mathrm{~m}$ along the flight line. The number of layers varies between 5 and 6 , however for the Glückstadt survey, smooth multilayer mod- els were available. Considering the relative stationarity of the groundwater $\mathrm{Cl}$ distribution, time differences between the surveys are acceptable (De Louw et al. 2011).

For each borehole in the study area with petrographic information, the nearest HEM data point was identified and the corresponding petrography class and FF were assigned at each meter depth of the HEM resistivity model $\left(\mathrm{R}_{\mathrm{b}}\right.$ data).

\section{Estimation of groundwater electrical conductivity $\left(E C_{w}\right)$}

Using the information of $\mathrm{R}_{\mathrm{b}}[\Omega \mathrm{m}]$ and $\mathrm{FF}$ at each meter depth of the selected HEM data points, $\mathrm{EC}_{\mathrm{w}}[\mathrm{S} / \mathrm{m}]$ was derived by:

$\mathrm{EC}_{\mathrm{w}}=\mathrm{FF} / \mathrm{R}_{\mathrm{b}}$

This relation is valid for clay-free sediments. Drilling results show that clayey sediments mainly occur in the Geest area with the exception of the clayey near-surface layer in the marshlands.

\section{Relation between $\mathrm{EC}_{\mathrm{w}}$ and $\mathrm{Cl}$}

$\mathrm{EC}_{\mathrm{w}}$ is usually used as a salinity indicator. Since chloride ions are the main constituents in groundwater and in saline sediments that directly affect $\mathrm{EC}_{\mathrm{w}}$, chloride concentrations in groundwater can be an indicator of the degree of saline intrusion (Peinado-Guevara et al. 2012).

Lower Saxony Water Management, Coastal Protection and Nature Conservation Agency (NLWKN) provides a database of measured $\mathrm{Cl}$ content and $\mathrm{EC}_{\mathrm{w}}$ values mea- 
sured at $25^{\circ} \mathrm{C}$. The dataset used in this paper contains 1936 $\mathrm{EC}_{\mathrm{w}}-\mathrm{Cl}$ pairs from 67 groundwater-monitoring stations. We applied the $\mathrm{EC}_{\mathrm{w}}$ temperature compensation relation (Sorensen and Glass 1987) defined by:

$\mathrm{EC}_{\mathrm{w} 25}=\mathrm{EC}_{\mathrm{wt}} /(1+\alpha(\mathrm{t}-25))$

Here, $\mathrm{EC}_{\mathrm{wt}}$ is the $\mathrm{EC}_{\mathrm{w}}$ at $10^{\circ} \mathrm{C}$, the mean groundwater temperature at the study area. In Eq. $4, \alpha$ is a temperature compensation factor which was recommended as 0.0191 by Clesceri et al. (1998).

In many studies (e.g., De Louw et al. 2011) a strong correlation between $\mathrm{EC}_{\mathrm{w}}$ and $\mathrm{Cl}$ has been found. We applied a linear regression analysis to determine the correlation between $\mathrm{EC}_{\mathrm{w}}$ and chloride concentration $\mathrm{Cl}(\mathrm{mg} / \mathrm{l})$ from groundwater samples:

$\mathrm{Cl}=\mathrm{m} \cdot \mathrm{EC}_{\mathrm{w} 25}+\mathrm{c}$

where $\mathrm{m}$ and $\mathrm{c}$ are regression coefficients.

The high electrical conductivity of groundwater in the study area $(>2000 \mu \mathrm{S} / \mathrm{cm})$ is mostly dominated by chloride and sodium ions, although the piper diagram presented by Rahman et al. (2018) shows that $\mathrm{Ca}\left(\mathrm{HCO}_{3}\right)_{2}$ and $\mathrm{Mg}\left(\mathrm{HCO}_{3}\right)_{2}$ are also present in the groundwater. To avoid uncertainties involved in bicarbonate measurement and to consider that the electrical conductivity is not linearly related to the $\mathrm{Cl}$ concentration (De Louw et al. 2011), we separated the entire data set into three classes. Therefore, three different regression analyses were performed. The classifications based on the range of groundwater conductivity were freshwater $\left(\mathrm{EC}_{25}<500 \mu \mathrm{S} / \mathrm{cm}\right)$, brackish water $\left(500 \mu \mathrm{S} / \mathrm{cm}<\mathrm{EC}_{25}<2000 \mu \mathrm{S} / \mathrm{cm}\right)$ and saline water $\left(\mathrm{EC}_{25}\right.$ $>2000 \mu \mathrm{S} / \mathrm{cm}$ ). Using the regression analysis results, we converted all estimated $\mathrm{EC}_{\mathrm{w}}(\mu \mathrm{S} / \mathrm{cm})$, derived from HEM resistivity $(\Omega \mathrm{m})$ and borehole data, to $\mathrm{Cl}$ concentration (mg/l).

After the regression analysis, the relations were validated against the measured $\mathrm{EC}_{25}$ and $\mathrm{Cl}$ from 350 samples from direct push tests in 2017 and 2018 provided by LBEG.

\section{2-D interpolation of chloride data}

Instead of interpolating FF values, we chose chloride values to interpolate all data in the entire area because the chloride distribution in the groundwater is smoother than the FF distribution which is rather heterogeneous due to spatial and vertical variability of the petrography. The interpolation was based on a $100 \mathrm{~m}$ by $100 \mathrm{~m}$ grid using ordinary Kriging method with Auto Fit option. The $\mathrm{Cl}$ concentration was interpolated at different depths by Surfer 16.0 in the 64-bit version 16.0.330 (www.goldensoftware.com).

\section{Manual inspection, validation and adjustment of $\mathrm{Cl}$} distribution

The groundwater in the Geest area is considered freshwater, i.e., the $\mathrm{Cl}$ concentration in groundwater is less than $250 \mathrm{mg} / \mathrm{l}$, the threshold set for drinking water in Germany (BMJV 2001).

The initial interpolation results showed relatively higher $\mathrm{Cl}$ concentration in some areas due to clayey material, e.g. the Lauenburger Clay on top of a tunnel valley. To avoid such visible and unrealistic errors, we performed some manual validation (e.g., checking resistivity and borehole petrography information) and adjustment for the Geest area. The fresh saline water interface defined by the resistivity limit of $30 \Omega \mathrm{m}$ (Repsold 1990; Deus et al. 2015) is found at the Geest-Marsch boundary. First, we deleted resistivity values below $R_{b}=30 \Omega m$ in the Geest area. Second, we decided to set the maximum $\mathrm{Cl}$ concentration to $250 \mathrm{mg} / \mathrm{l}$ in the Geest area. Finally, the new dataset was re-interpolated. The interpolation was done for each meter depth below the surface of the vertical extent covered by the survey area.

\section{Results and discussion}

\section{Formation factor for the petrography classes}

Table 3 shows the porosity and formation factor of each petrography class. For completeness, formation factors of coarse sand, silt, sandy clay, and clayey sand were taken from De Louw et al. (2011) or Goes et al. (2009) who investigated comparable sites in the Netherlands. In addition, because of the invalidity of Eq. 1 for cohesive materials (in which the porosity must be below 0.6 , and surface conductivity which is common to clayey material is neglected), the apparent formation factor of clay and peat were also taken from the literature. Due to a lack of available information on the formation factor of silty clay and clayey silt, we assigned formation factors of clay and silt, respectively.

\section{Resistivity and petrography classes}

Measured resistivities $\left(\mathrm{R}_{\mathrm{b}}\right)$ from HEM data were grouped in a box plot, which shows that the median resistivity value of most petrography classes increases with the increase of grain size, except in the case of peat (no grains) and gravel (Fig. 2a). The highest median resistivity occurs in coarse sand with only $70 \Omega \mathrm{m}$, and the lowest resistivity is in clay, around $20 \Omega \mathrm{m}$. Medium sand shows the largest spectrum of resistivity values ranging between $10 \Omega \mathrm{m}$ and $140 \Omega \mathrm{m}$, while silty clay has the smallest range, between $15 \Omega \mathrm{m}$ and $35 \Omega \mathrm{m}$. The resistivity occurrence of some selected classes shows the dominance of sandy material (Fig. 2b). The most 
Fig. 2 a Box plot of resistivity from HEM data for each petrography class (increase of grain size on $\mathrm{x}$-axis); $\mathbf{b}$ resistivity occurrence from HEM data for selected petrography classes (sand comprises fine, medium and coarse sand)

Abb. 2 a Box-Plot des spezifischen elektrischen Widerstands aus HEM-Daten für jede Petrografieklasse (auf X-Achse mit zunehmender Korngröße aufgetragen); b Widerstandshäufigkeit für ausgewählte Petrografieklassen abgeleitet aus HEM-Daten (Sand beinhaltet Fein-, Mittelund Grobsand)

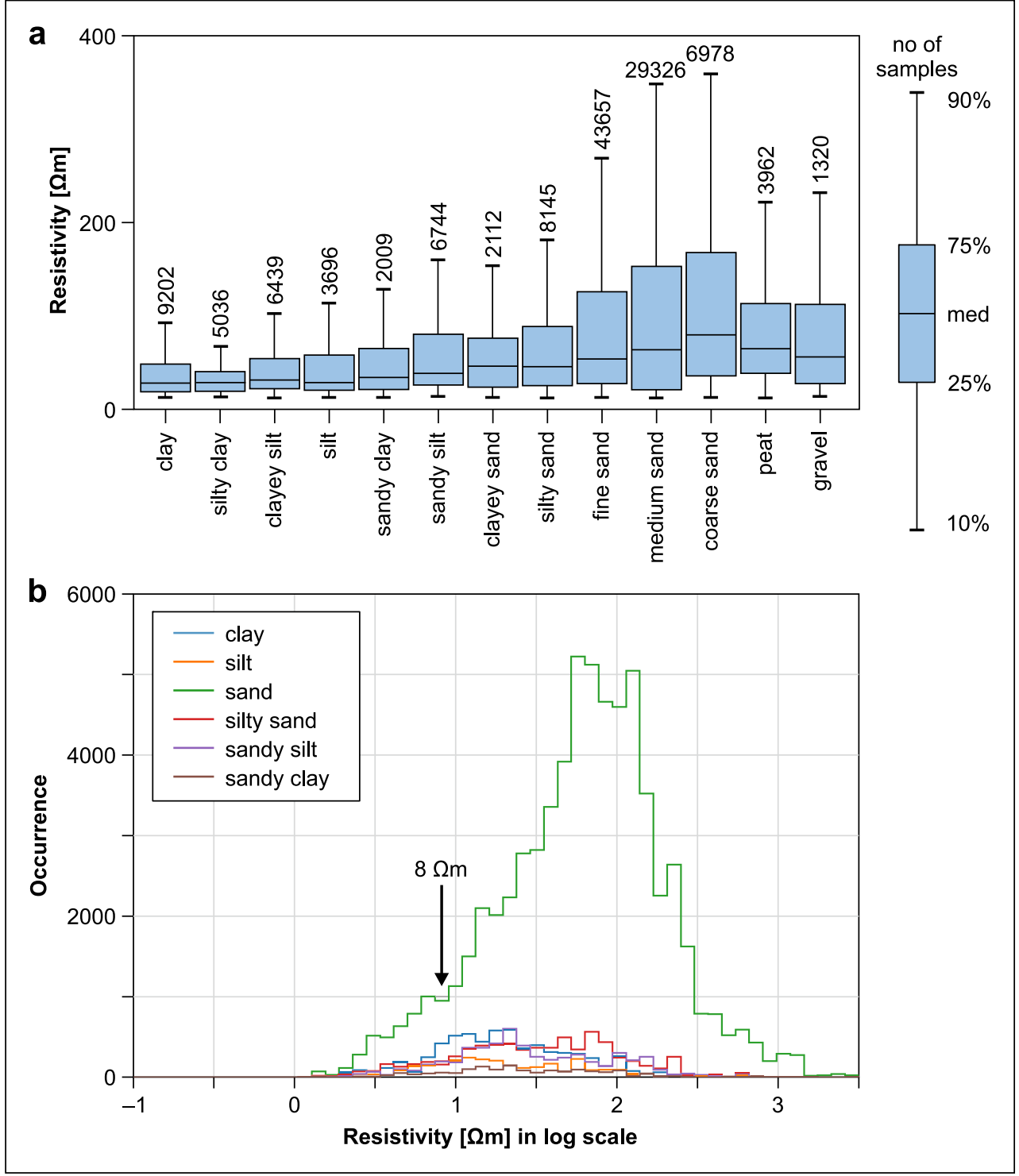

frequently occurring resistivities for the sand fraction are in the range of $80 \Omega \mathrm{m}$, which corresponds to the freshwatersaturated sands in the Geest areas. The accumulated values in the lower resistivity range are interpreted as saline watersaturated sands in the marshlands; the minimum at about $8 \Omega \mathrm{m}$ is suggested to define the threshold to the saline affected sands. This relatively straightforward interpretation of the histogram is consistent with Wiederhold and Ullmann (2017); Siemon et al. (2019) also discuss such low resistivity threshold values for fresh-saline groundwater interfaces.

\section{Relation between $\mathrm{EC}_{\mathrm{w}}$ and $\mathrm{Cl}$}

Fig. 3 illustrates the regression analysis and its validation for groundwater samples of each $\mathrm{EC}_{\mathrm{w}}$ group. The result of the regression analysis with $\mathrm{R}^{2}$ and number of samples $(n)$ is:

Freshwater :

$\mathrm{Cl}[\mathrm{mg} / \mathrm{l}]=0.0933 \mathrm{EC}_{\mathrm{w}}[\mu \mathrm{S} / \mathrm{cm}]+0.254$;

$\left(\mathrm{R}^{2}=0.61 ; n=1267\right)$

Brackish water :

$\mathrm{Cl}[\mathrm{mg} / \mathrm{l}]=0.259 \mathrm{ECw}[\mu \mathrm{S} / \mathrm{cm}]-96.064$;

$\left(\mathrm{R}^{2}=0.62 ; n=421\right)$

Saline water :

$\mathrm{Cl}[\mathrm{mg} / \mathrm{l}]=0.358 \mathrm{ECw}[\mu \mathrm{S} / \mathrm{cm}]-535.72$; 


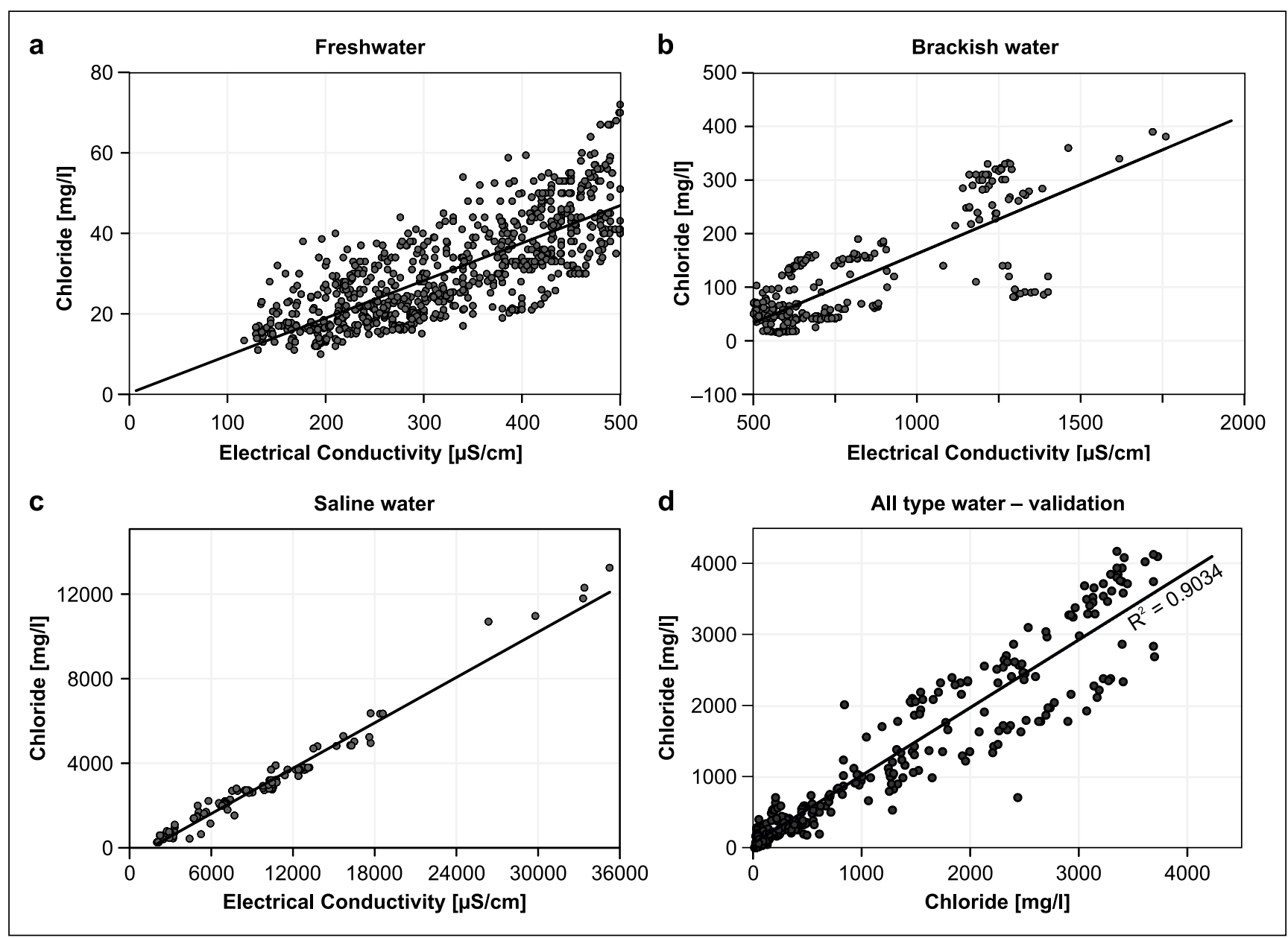

Fig. 3 Relation between $\mathrm{EC}_{\mathrm{w}}$ and $\mathrm{Cl}$ for $\mathbf{a}$ freshwater, $\mathbf{b}$ brackish water and $\mathbf{c}$ saline water; $\mathbf{d}$ observed (x-axis) and estimated (y-axis) $\mathrm{Cl}$ value as validation of the regression analysis $\left(\mathrm{R}^{2}=0.90\right)$

Abb. 3 Beziehung zwischen $\mathrm{EC}_{\mathrm{w}}$ und Cloridgehalt für a Süßwasser, b Brackwasser und $\mathbf{c}$ Salzwasser; $\mathbf{d}$ beobachteter (x-Achse) und abgeleiteter (y-Achse) Cl-Wert zur Validierung der Regressionsanalyse $\left(\mathrm{R}^{2}=0,90\right)$

De Louw et al. (2011) considered the relation between $\mathrm{Cl}$ and $\mathrm{EC}_{\mathrm{w}}$ as follows:

$\mathrm{Cl}[\mathrm{mg} / \mathrm{l}]=0.360 \mathrm{ECw}[\mu \mathrm{S} / \mathrm{cm}]-450$;

$\left(\mathrm{R}^{2}=0.98 ; n=79\right)$

which is in good agreement with the relation of our saline water samples. De Louw et al. (2011) considered a single relation but which was only valid from a $\mathrm{EC}_{\mathrm{w}}$ of about $2000 \mu \mathrm{S} / \mathrm{cm}$, above which the linearly related $\mathrm{Cl}-$ and $\mathrm{Na}+$ ions dominate the electrical conductivity (Delsman et al. 2018).

We used Eqs. 6-8 to convert $\mathrm{EC}_{\mathrm{w}}$ derived from HEM resistivity to $\mathrm{Cl}$ concentration.

\section{$\mathrm{Cl}$ distribution in the aquifers}

Fig. 4 shows the different steps to obtain the chloride distribution from the $\mathrm{R}_{\mathrm{b}}$ distribution, and the resistivity chloride conversion, omitting resistivities below $30 \Omega \mathrm{m}$ in the Geest area and additionally setting the maximum chloride value to $250 \mathrm{mg} / \mathrm{l}$ in the Geest area. Fig. 5 shows the final maps for different elevations down to $-60 \mathrm{~m}$ ASL. The high chloride concentration in the groundwater occurs mainly in the marshlands close to the seaside; the high salinity is also distributed along the Elbe River and Oste River. The saline area expands with the decrease in elevation, as higher chloride concentrations are also present in the lower part of the seaside. However, below $-50 \mathrm{~m}$ ASL, the resistivity information from the HEM survey as well as lithology information is scarce and cannot provide good interpolation results.

\section{Discussion on errors and uncertainties}

We identified the following uncertainties that might contribute to the erroneous $\mathrm{Cl}$ distribution. 


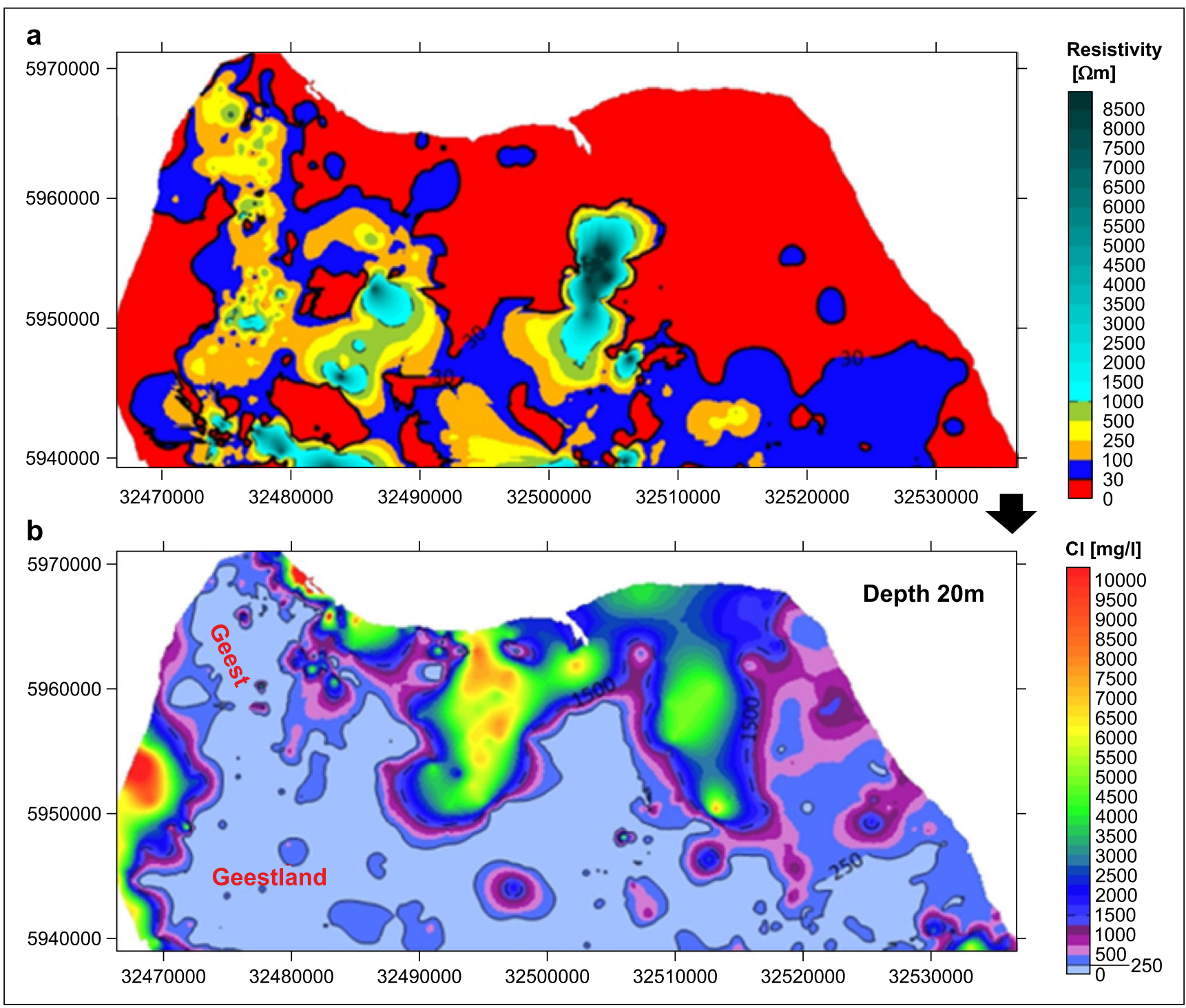

Fig. 4 a Resistivity distribution, $\mathrm{b} \mathrm{Cl}$ distribution obtained after conversion

Abb. 4 a Verteilung der spezifischen elektrischen Widerstände, $\mathbf{b}$ abgeleitete Cl-Verteilung

\section{Analysis of borehole information}

The deduction of petrography classes and formation factors from well information depends on the quality of the sediment profiles. Different drilling methods and thus associated uncertainties in sediment description need to be considered. In hydraulic circulation drillings, for example, the fine grain content is often underestimated. Another problem can be the simplification in the description of the sediment profiles, which is based on the subjective view of the responsible geologist.

\section{Formation factor estimation}

The sampling procedure for grain size analysis can lead to errors and uncertainties in follow-up estimations. Grain size analyses provide a quick overview of the grainsize distribution and the porosity. Because of the very high spatial variation in the composition of Quaternary sediments, the results are only valid for the sampling location. In addition, the method does not take the alignment and the compaction of the sediment into account, and results could differ from real conditions.

Porosity is calculated from grain size analysis using the coefficient of uniformity (Eq. 2). If the content of fine grain material is underestimated, as some of the fine material might be lost in the mud, the uniformity $(\mathrm{d} 60 / \mathrm{d} 10)$ will be 


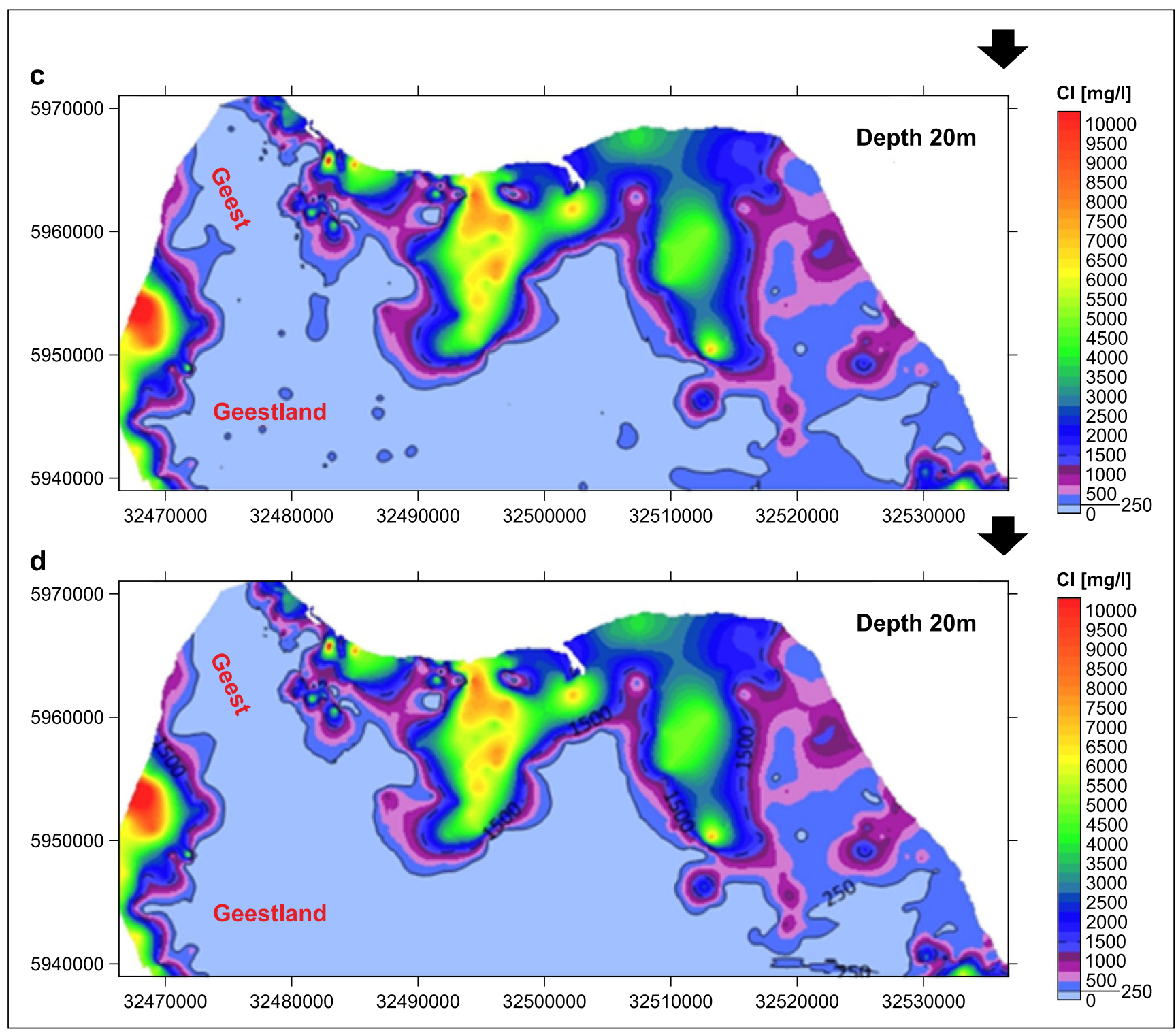

Fig. $4 \mathrm{c} \mathrm{Cl}$ distribution after deleting $30 \Omega \mathrm{m}$ in the Geest area, $\mathbf{d ~ C l}$ distribution after setting $250 \mathrm{mg} / \mathrm{l} \mathrm{Cl}$ in the Geest area. Resistivity and chloride distribution are at $20 \mathrm{~m}$ depth below surface; for data distribution see Fig. 5

Abb. 4 c Cl-Verteilung nach Anwendung des $30 \Omega \mathrm{m}$-Kriteriums im Geest-Gebiet, d Cl-Verteilung nach Festsetzung eines maximalen Chloridgehalts von $250 \mathrm{mg} / \mathrm{l}$ im Geest-Gebiet. Der spezifische Widerstand und die Chloridverteilung beziehen sich auf $20 \mathrm{~m}$ Tiefe unter Geländeoberfläche, die Datenverteilung ist in Fig. 5 dargestellt

too low leading to an overestimate of porosity. This results in an underestimate of the formation factor. Additionally, the porosity exponent in Eq. 1 is set to 1.5 following Taylor Smith (1971), but for unconsolidated sediments it can be in the range of 1.3-2. Values from Goes et al. (2009) imply porosity exponents (cementation factors) of 1.9 for coarse sand and 1.7 for gravel (Table 3), while other authors, e.g., Repsold (1989), used the modified Humble formula ( $\mathrm{FF}=$ $\left.0.81 \phi^{-2}\right)$.

Comparing formation factors for a porosity of 0.4 calculated after Taylor Smith, Goes and Repsold leads to an uncertainty of about $25 \%$. Therefore, the uncertainty in poros- ity estimation from uniformity can be neglected against the uncertainty resulting from porosity exponent errors.

For drillings where no porosity data are available, the formation factors were assigned to the layers according to the particular petrography class. Here the same uncertainty must be taken into account.

The applied method for formation factor estimation is valid for clay-free material only. In this study, areas with the possibility of clay occurrence (e.g. in the Geest area) were excluded. Even in the marshlands the clay content is low compared to the sand fraction as shown in the histograms of Fig. 2b. 


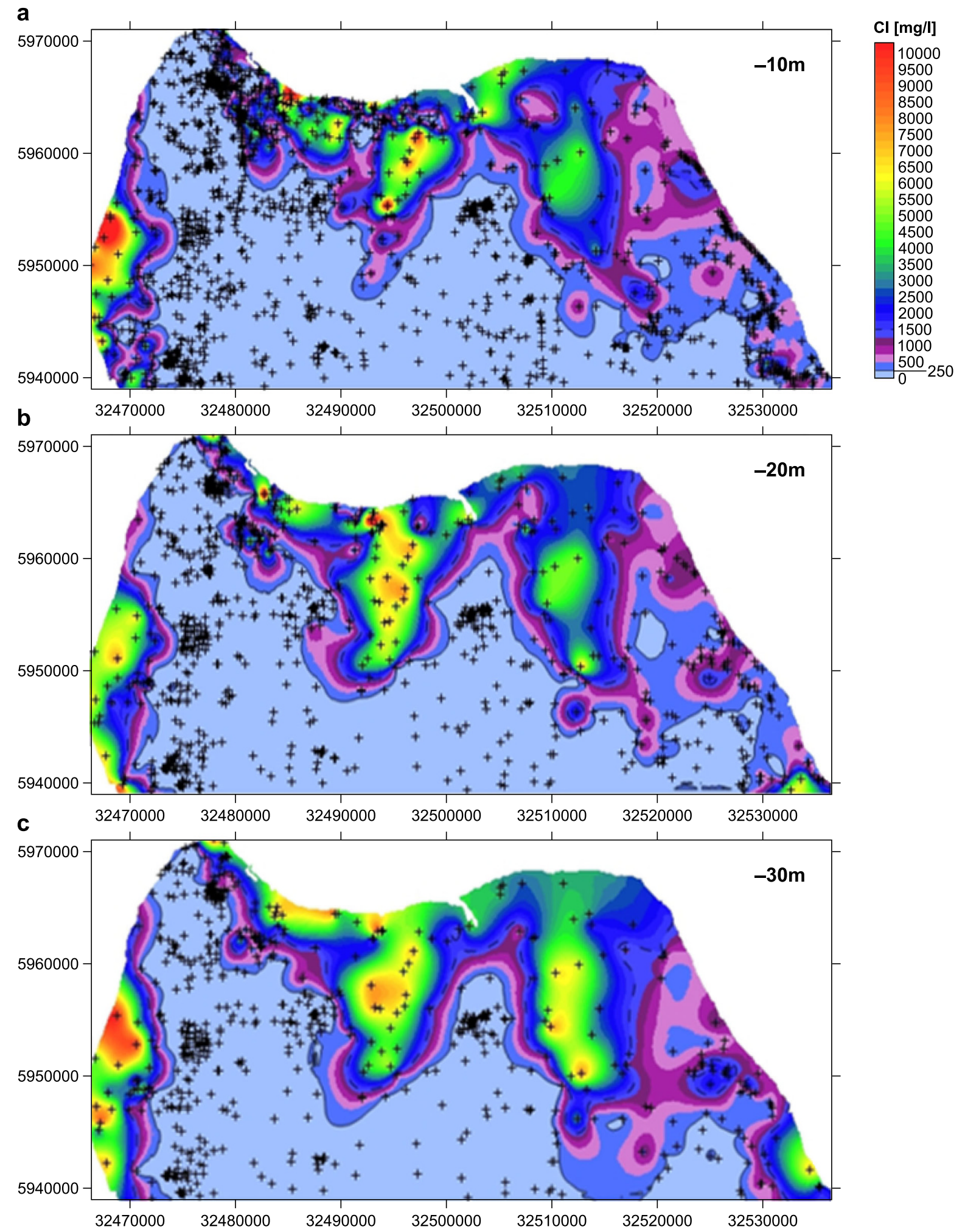

Fig. 5 Spatial and vertical chloride distribution at $-10,-20,-30,-40,-50,-60 \mathrm{~m}$ ASL (black dots indicate the information control points used for interpolation)

Abb. 5 Flächenhafte und vertikale Chloridverteilung in $-10,-20,-30,-40,-50$ und $-60 \mathrm{~m}$ NHN (die Punkte zeigen die Stützstellen der Interpolation an) 


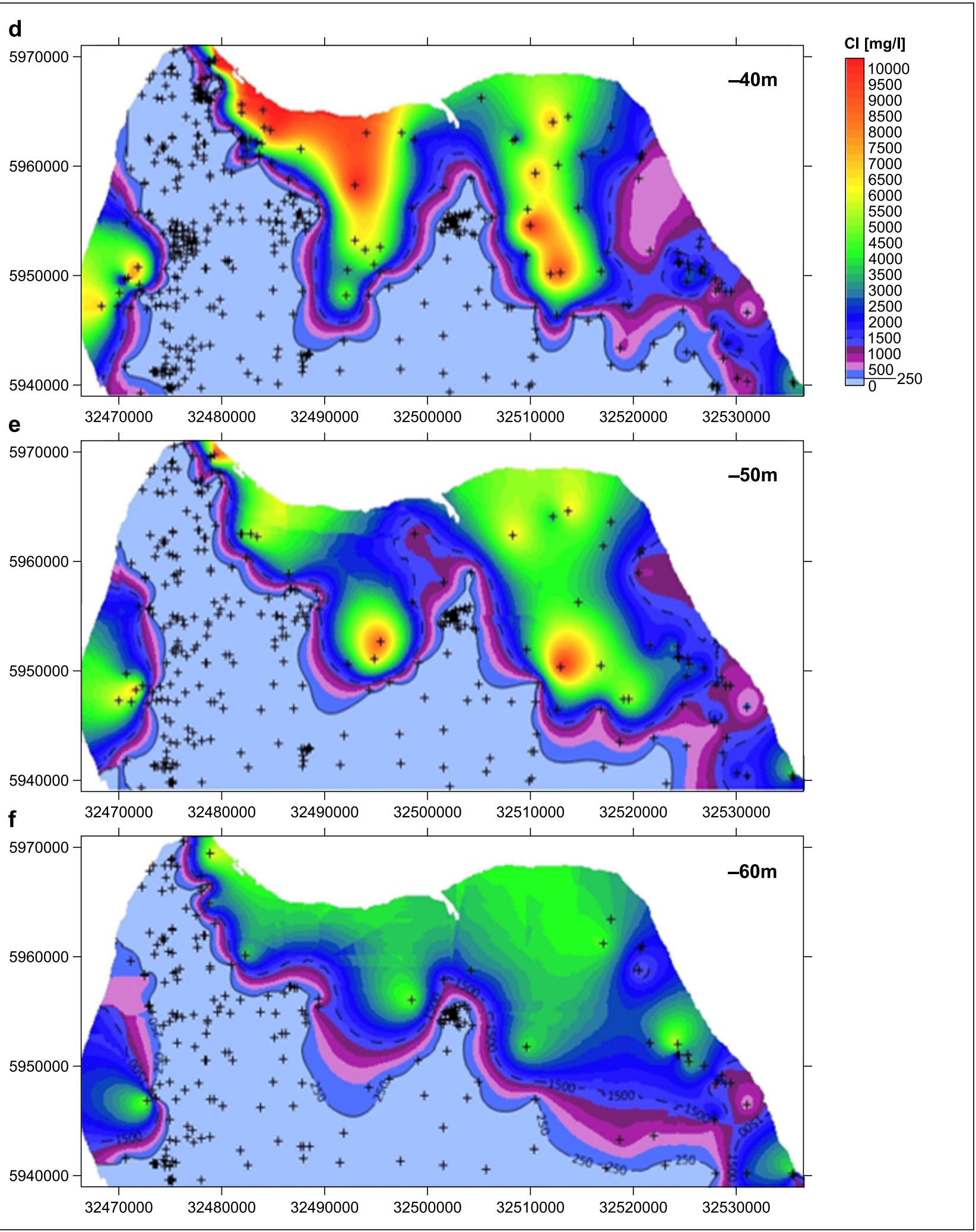

Fig. 5 (continued)

Abb. 5 (Fortsetzung) 


\section{HEM data and inversion}

As measured data always have errors, even after thorough data processing, the derived physical parameters are also biased, particularly if they are the result of an optimization process being prone to over-interpretation, e.g., the inversion of HEM data to resistivity-depth models. The resulting 1D models used in this study represent only one solution explaining the data. Such a solution is always a simplified image of the subsurface. Comparison studies (e.g., Delsman et al. 2018 and King et al. 2018), however, demonstrated that the majority of models were able to reveal the principle layered resistivity features. A further challenge occurs if the subsurface is strongly heterogeneous in the lateral direction. In this case, $1 \mathrm{D}$ models may fail to explain the data, and 2D/3D modelling or inversion is required. Fortunately, this point is not essential here.

\section{Assigning petrography class to HEM data at different depths}

At the HEM resistivity model location, we assigned petrography from the nearest available (proximity max. $100 \mathrm{~m}$ ) borehole. Considering the geologic and petrographic heterogeneity at the study area, assigned petrography might not be accurate. Therefore, the formation factor, which is related to petrography, might also be inaccurate. Subsequently, erroneous results can be generated. In a regional aquifer system, it is challenging to resolve the spatial and vertical heterogeneity in an automated process. Manual inspection definitely reduces the uncertainty but time and resources would be vital.

\section{Estimation of groundwater electrical conductivity $\left(E_{\mathrm{w}}\right)$}

$\mathrm{EC}_{\mathrm{w}}$ is estimated from the bulk resistivity and formation factor. Since both quantities are linearly related, the $25 \%$ uncertainty of the formation factor leads to the same amount of uncertainty in $\mathrm{EC}_{\mathrm{w}}$. Additionally, a uniform groundwater temperature of $10^{\circ} \mathrm{C}$ is assumed that also corresponds to the average temperature of groundwater samples at the study area (average value of 204 samples is $10.1{ }^{\circ} \mathrm{C}$ and $\varepsilon$ is 0.92 ). The spatial variation in temperature is between $13.1^{\circ} \mathrm{C}$ and $8.4^{\circ} \mathrm{C}$, which is non-uniform and might contribute uncertainty in the $\mathrm{EC}_{\mathrm{w}}$ estimation by $+8 \%$ to $-4 \%$.

\section{Relation between $\mathrm{EC}_{\mathrm{w}}$ and $\mathrm{Cl}$}

We considered that $\mathrm{Na}+$ and $\mathrm{Cl}-$ dominate the electrical conductivity through the entire range of $\mathrm{EC}_{\mathrm{w}}$ data available, although the linear relation may only be valid at higher $\mathrm{EC}_{\mathrm{w}}$ $(>2000 \mu \mathrm{S} / \mathrm{cm}$ ) (De Louw et al. 2011). Below this limit, other ions, such as bicarbonate ion $\left(\mathrm{HCO}_{3}^{-}\right)$due to the presence of $\mathrm{Ca}\left(\mathrm{HCO}_{3}\right)_{2}$ and $\mathrm{Mg}\left(\mathrm{HCO}_{3}\right)_{2}$, also might influence the $\mathrm{EC}_{\mathrm{w}}$ (Goes et al. 2009). The $\mathrm{Cl}$ concentration might therefore be overestimated.

\section{Interpolation error}

In addition to the above problems, interpolation error can also be considered as one of the main issues that generates error in the chloride distribution. In our case study, the data points were neither evenly nor densely distributed, and therefore, the interpolation methods might produce some deviation from the true chloride distribution.

\section{Conclusions}

Despite many uncertainties, the 3D chloride distribution in the aquifer of the study area was determined by HEM data in combination with borehole data, grain size analysis and laboratory results on the relation of CL content and electrical conductivity from groundwater samples. A threshold value of $8 \Omega \mathrm{m}$ for saline-affected sandy glacial sediments was found by a statistical analysis of HEM resistivity data.

The database was substantially enlarged by the HEM data, nonetheless, the full data density of HEM has not yet been exploited. HEM resistivity data were taken only to determine formation factors in the surrounding boreholes. The chloride concentrations obtained at the borehole locations were interpolated. Resistivity variations from between boreholes as seen in the HEM data, indicating lateral changes in the geology, were not taken into account. For future studies, one has to consider interpolation methods that take the geology into account to be able to use the full HEM data set for interpolation of $\mathrm{Cl}$ concentrations.

The estimated $\mathrm{EC}_{\mathrm{w}}$ can be useful to generate a densitydriven groundwater model. The $\mathrm{EC}_{\mathrm{w}}$ data could be used as an initial condition when the generation of initial condition considering a historical change in natural recharge and other boundaries (such as seaside boundary, historical flooding) is not possible.

The fresh-saline groundwater interface derived in this study can be validated and investigated in detail with densely-spaced surface measurements, e.g. with $2 \mathrm{D}$ or $3 \mathrm{D}$ ERT.

The grouping of borehole data in terms of petrography classes as applied in this study was used to determine a depth profile of porosities and formation factors. This method can be extended to other petrophysical characteristics such as, for example, hydraulic conductivity and verified by borehole NMR. This can lead to an extended database for groundwater modelling. 
Acknowledgements The TOPSOIL project is co-funded by the Interreg North Sea Region Programme (J No 38227 15). We thank NLWKN for providing the database of measured $\mathrm{Cl}$ content and $\mathrm{EC}_{\mathrm{W}}$ values. The manuscript was improved by the comments of two reviewers.

Funding Open Access funding enabled and organized by Projekt DEAL.

Open Access This article is licensed under a Creative Commons Attribution 4.0 International License, which permits use, sharing, adaptation, distribution and reproduction in any medium or format, as long as you give appropriate credit to the original author(s) and the source, provide a link to the Creative Commons licence, and indicate if changes were made. The images or other third party material in this article are included in the article's Creative Commons licence, unless indicated otherwise in a credit line to the material. If material is not included in the article's Creative Commons licence and your intended use is not permitted by statutory regulation or exceeds the permitted use, you will need to obtain permission directly from the copyright holder. To view a copy of this licence, visit http://creativecommons.org/licenses/by/4. $0 \%$.

\section{References}

Archie, G.E.: The electrical resistivity $\log$ as an aid in determining some reservoir characteristics. Trans. Am. Inst. Mech. Eng. 146, 54-62 (1942)

Barlow, P., Reichard, G.E.: Saline water intrusion in coastal regions of North America. Hydrogeol J 18, 247-260 (2010). https://doi.org/ 10.1007/s10040-009-0514-3

BMJV: Grundwasserverordnung. Bundesministerium der Justiz und für Verbraucherschutz, Berlin (2001)

Chongo, M., Christiansen, A.V., Tembo, A., Banda, K.E., Nyambe, I.A., Larsen, F., Bauer-Gottwein, P.: Airborne and ground-based transient electromagnetic mapping of groundwater salinity in the Machile-Zambezi Basin, southwestern Zambia. Near Surf. Geophys. 13, 383-395 (2015). https://doi.org/10.3997/1873-0604. 2015024

Christiansen, A.V., Auken, E.: A global measure for depth of investigation. Geophysics 77(4), WB171-WB177 (2012). https://doi. org/10.1190/GEO2011-0393.1

Clesceri, L.S., Greenberg, A.E., Eaton, A.D.: Standard methods for the examination of water and wastewater, 20th edn. American Public Health Association, Washington, D.C. (1998)

Cosgrove, W.J., Loucks, D.P.: Water management: current and future challenges and research directions. Water Resour. Res. 51, 6 (2015). https://doi.org/10.1002/2014WR016869

De Louw, P.G., Eeman, S., Siemon, B., Voortman, B.R., Gunnink, J., van Baaren, E.S., Essink, G.H.: Shallow rainwater lenses in deltaic areas with saline seepage. Hydrol. Earth Syst. Sci. 15, 3659-3678 (2011). https://doi.org/10.5194/hess-15-3659-2011

Delsman, J.R., van Baaren, E.S., Siemon, B., Dabekaussen, W., Karaoulis, M., Pauw, P., Vermass, T., Bootsma, H., de Louw, P.G.B., Gunnink, J.L., Dubelaar, W., Menkovic, A., Steuer, A., Meyer, U., Revil, A., Oude Essink, G.H.P.: Large-scale, probabilistic salinity mapping using airborne electromagnetics for groundwater management in Zeeland, the Netherlands. Environ. Res. Lett. 13(8), 1-12 (2018). https://doi.org/10.1088/1748-9326/ aad $19 \mathrm{e}$

Deus, N., Elbracht, J., Siemon, B.: 3D-Modelling of the salt-/fresh water interface in coastal aquifers of Lower Saxony (Germany) based on airborne electromagnetic measurements (HEM). In: Proceedings of aquaconsoil, 13th international UFZ-Deltares conference on sustainable use and management of soil, sediment and water resources Copenhagen, 09.-12.06.2015. (2015)
Dogrul, E.C., Brush, C.F., Kadir, T.N.: Groundwater modeling in support of water resources management and planning under complex climate, regulatory, and economic stresses. Water $\mathbf{8}(12), 592$ (2016). https://doi.org/10.3390/w8120592

Ehlers, J.: Das Eiszeitalter. Spektrum Akademischer Verlag, Heidelberg (2011)

Elbracht, J., Meyer, R., Reutter, E.: Hydrogeologische Räume und Teilräume in Niedersachsen. GeoBerichte 3, 118. Landesamt für Bergbau, Energie und Geologie, Hannover (2016)

Goes, B.J.M., Oude Essink, G.H.P., Vernes, R.W., Sergi, F.: Estimating the depth of fresh and brackish groundwater in a predominantly saline region using geophysical and hydrological methods, Zeeland, the Netherlands. Near Surf. Geophys. 7, 401-412 (2009). https://doi.org/10.3997/1873-0604.2009048

González, E., Deus, N., Elbracht, J., Rahman, M.A., Wiederhold, H.: Current and future state of groundwater salinization of the northern Elbe-Weser region. Grundwasser - Zeitschrift der Fachsektion Hydrogeologie 26 (2021)

Gunnink, J., Bosch, J.H.A., Siemon, B., Roth, B., Auken, E.: Combining ground-based and airborne EM through Artificial Neural Networks for modelling glacial till under saline groundwater conditions. Hydrol. Earth Syst. Sci. 16, 3061-3074 (2012). https:// doi.org/10.5194/hess-16-3061-2012

Höfle, H.-C., Merkt, J., Müller, H.: Die Ausbreitung des Eem-Meeres in Nordwestdeutschland. EG Quat. Sci. J. 35, 49-60 (1985). https://doi.org/10.3285/eg.35.1.09

King, J., Oude Essing, G., Karaoulis, M., Siemon, B., Bierkens, M.F.P.: Quantifying inversion algorithms using airborne frequency domain electromagnetic data-applied at the Province of Zeeland, the Netherlands. Water Resour. Res. 54(10), 8420-8441 (2018). https://doi.org/10.1029/2018WR023165

Kirkegaard, C., Sonnenborg, T.O., Auken, E., Jørgensen, F.: Salinity distribution in heterogeneous coastal aquifers mapped by airborne electromagnetics. Vadose Zone J. 10(1), 125-135 (2011). https:// doi.org/10.2136/vzj2010.0038

Kumar, K.S.A., Priju, C.P., Prasad, N.B.N.: Study on saline water intrusion into the shallow coastal aquifers of Periyar River Basin, Kerala using hydrochemical and electrical resistivity methods. Aquat. Procedia 4, 32-40 (2015). https://doi.org/10.1016/j.aqpro.2015. 02.006

Kuster, H., Meyer, K.-D.: Glaziäre Rinnen im mittleren und nordöstlichen Niedersachsen. EG Quat. Sci. J 29, 135-156 (1979). https://doi.org/10.3285/eg.29.1.12

LBEG: Symbolschlüssel Geologie - Navigator (Symbol keys Geology - Navigator). Landesamt für Bergbau Energie und Rohstoffe, Hannover (2018). https://syschl.lbeg.de/sys_start.php. Accessed 10 May 2019

Margane, A.: Guideline for groundwater monitoring. In: Management, protection and sustainable use of groundwater and soil resources in the Arab region Technical Cooperation, project no. 1996.2189.7, vol. 7, Bundesanstalt für Geowissenschaften und Rohstoffe, Hannover (2004)

NIBIS ${ }^{\circledR}$ Kartenserver: Hydrogeologische Übersichtskarte Karte 1:200000 „Grundwasserneubildung, Methode mGROWA“ (Generalised hydrogeological map of Lower Saxony, 1: 200000 "Groundwater recharge, mGROWA"). Landesamt für Bergbau Energie und Rohstoffe, Hannover (2018)

Paine, J.G.: Determining salinization extent, identifying salinity sources, and estimating chloride mass using surface, borehole, and airborne electromagnetic induction methods. Water Resour. Res. 39(3), 1059 (2003). https://doi.org/10.1029/2001WR000710

Paine, J.G., Minty, R.S.: Airborne hydrogeophysics. In: Rubin, Y., Hubbard, S.S. (eds.) Hydrogeophysics, pp. 333-357. Springer, Dordrecht (2005)

Pedersen, J.B., Schaars, F.W., Christiansen, A.V., Foged, N., Schamper, C., Rolf, H., Auken, E.: Mapping the fresh-saline water interface in the coastal zone using high-resolution airborne electromagnet- 
ics. First Break 35, 57-61 (2017). http://fb.eage.org/publication/ content?id=89806

Peinado-Guevara, H., Green-Ruíz, C., Herrera-Barrientos, J., EscoleroFuentes, O., Delgado-Rodríguez, O., Belmonte-Jiménez, S., Guevara, M.L.: Relationship between chloride concentration and electrical conductivity in groundwater and its estimation from vertical electrical soundings (VESs) in Guasave, Sinaloa, Mexico. Ciencia E Investig. Agrar. 39(1), 229-239 (2012). https://doi.org/10. 4067/s0718-16202012000100020

Produktcenter BGR: (2017). https://produktcenter.bgr.de/. Accessed 14 Apr 2020

Rahman, M.A., González, E., Wiederhold, H., Deus, N., Elbracht, J., Siemon, B.: Characterization of a regional coastal zone aquifer using an interdisciplinary approach - an example from Weser-Elbe region, Lower Saxony, Germany. Proceedings of 25th SWIM conference, E3S Web of Conferences, 54, 00026 . (2018)

Repsold, H.: Well logging in groundwater development. International Association of Hydrogeologists, vol. 9. International Contributions to Hydrogeology, Hannover (1989)

Repsold, H.: Geoelektrische Untersuchungen zur Bestimmung der Süßwasser-/Salzwasser-Grenze im Gebiet zwischen Cuxhaven und Stade. Geol. Jahrb. C56, 3-37 (1990)

Reutter, E.: Hydrostratigrafie. Geofakten 21. Landesamt für Bergbau, Energie und Geologie, Hannover (2011)

Sengpiel, K.-P., Siemon, B.: Advanced inversion methods for airborne electromagnetic exploration. Geophysics 65, 1983-1992 (2000). https://doi.org/10.1190/1.1444882

Siemon, B., van Baaren, E., Dabekaussen, W., Delsman, J., Dubelaar, W., Karaoulis, M., Steuer, A.: Automatic identification of fresh-saline groundwater interfaces from airborne electromagnetic data in Zeeland, the Netherlands. Near Surf. Geophys. 17, 3-25 (2019). https://doi.org/10.1002/nsg. 12028

Siemon, B., Christiansen, A.V., Auken, E.: A review of helicopterborne electromagnetic methods for groundwater exploration. Near Surf. Geophys. 7, 629-646 (2009). https://doi.org/10.3997/ 1873-0604.2009043

Siemon, B., Ibs-von Seht, M., Steuer, A., Deus, N., Wiederhold, H.: Airborne electromagnetic, magnetic, and radiometric surveys at the German North Sea Coast applied to groundwater and soil investigations. Remote Sens 12, 1629 (2020)

Siemon, B., Voß, W., Ibs-von Seht, M., Pielawa, J.: Technischer Bericht Hubschrauber-Geophysik Bremerhaven, Juni 2001 (Revision 2011). BGR-Bericht, Archiv-Nr. 0130162, Hannover. (2011)

Siemon, B., Voß, W., Ibs-von Seht, M., Pielawa, J., Röttger, B.: Technischer Bericht Hubschrauber-Geophysik - Cuxhaven Mai 2000 (Revision 2013). BGR-Bericht, Archiv-Nr. 0131409, Hannover. (2013)
Siemon, B., Voß, W., Kerner, T., Pielawa, J.: Technischer Bericht Hubschraubergeophysik Hadelner Marsch Mai/Juni 2004 (Revision 2017). BGR-Bericht, Archiv-Nr. 0134290, Hannover. (2017)

Smith, T.D.: Acoustic and electric techniques for sea-floor sediment identification. Proc. Int. Symp. on Engineering Properties of SeaFloor Soils and their Geophysical Identification, Seattle, Washington., pp 253-267 (1971)

Sorensen, J.A., Glass, G.E.: Ion and temperature dependence of electrical conductance for natural waters. Anal. Chem. 59, 1594-1597 (1987)

Steuer, A., Siemon, B., Ibs-von Seht, M., Pielawa, J., Voß, W.: Technischer Bericht Hubschraubergeophysik - Befliegung Glückstadt, Sommer 2008 - Frühjahr 2009. BGR-Bericht, Archiv-Nr. 0131097, Hannover. (2013)

Streif, H., Köster, R.: Zur Geologie der deutschen Nordseeküste. Die Küste 32, 30-50 (1978)

Sulzbacher, H., Wiederhold, H., Siemon, B., Grinat, M., Igel, J., Burschil, T., Günther, T., Hinsby, K.: Numerical modelling of climate change impacts on freshwater lenses on the North Sea Island of Borkum using hydrological and geophysical methods. Hydrol. Earth Syst. Sci. 16, 3621-3663 (2012). https://doi.org/ 10.5194/hess-16-3621-2012

Viezzoli, A., Tosi, L., Teatini, P., Silvestri, S.: Surface water-groundwater exchange in transitional coastal environments by airborne electromagnetics: The Venice Lagoon example. Geophys. Res. Lett. (2010). https://doi.org/10.1029/2009GL041572

Vukovic, M., Soro, A.: Determination of hydraulic conductivity of porous media from grain-size composition. Water Resources Publications, Littleton (1992)

van Weert, F., van der Gun, J., Reckman, J.: Global overview of saline groundwater occurrence and genesis. Utrecht. IGRAC Report no. GP 2009-1. (2009)

White, E., Kaplan, D.: Restore or retreat? saltwater intrusion and water management in coastal wetlands. Ecosyst. Health Sustain. (2017). https://doi.org/10.1002/ehs2.1258

Wiederhold, H., Ullmann, A.: INIS-Verbundprojekt NAWAK: Entwicklung Nachhaltiger Anpassungsstrategien für die Infrastrukturen der Wasserwirtschaft unter den Bedingungen des Klimatischen und Demografischen Wandels. Teilprojekt 4. BMBFSchlussbericht. Leibniz-Institut für Angewandte Geophysik (LIAG), Hannover (2017)

WSV: Online portal for data (2019). https://www.kuestendaten. de/Tideelbe/DE/dynamisch/Funktionen/Karte/index.php.html? do=mapStart.Accessed 10 July 2019

Publisher's Note Springer Nature remains neutral with regard to jurisdictional claims in published maps and institutional affiliations. 